\title{
Primal leadership:Leaders and their 360 degree review -A brief study
}

\author{
${ }^{1,}$ Prof .(Dr) AjeyaJha, ${ }^{2,}$ ArunimaSengupta, ${ }^{3}$ KunaalNaik, ${ }^{4,}$ Dr. Mariamma \\ Philips \\ 1: HOD Management Department SMIT 2: Ph.D Scholar Sikkim Manipal Institute of Technology (SMIT ) 3 : \\ Research Statistics expert 4: NIMHANS Bangalore
}

\begin{abstract}
There is a dearth of published research on leadership within the context healthcare field which makes this study particularly timely. Although there is extensive research on leadership, there still exists an acute need for leadership research based on follower perspectives (Lindebaum\& Cartwright, 2010; Notgrass, 2010). This study addresses this gap by investigating both leader self-perceptions and follower-perceptions of their leaders. Phase 1 focuses on the combination of leader self-perceptions and follower-perceptions of their leaders.

In Phase 1, this study considers both leader and follower perspectives and identifies leaders who overestimate, underestimate or are in-agreement with followers, in evaluating their own Leadership capabilities. Based on this, the leaders are classified into Average 4 and Average 5 in 360 degree leadership scores of the leaders.

Similar differences across the self-other-agreement categories of the leaders are predicted in terms of the linkage between EI and Transformational Leadership as perceived by the followers. The ontology of this research is realist and the epistemology is positivist. Phase 1, target population was identified as the direct reports of phase 1 participants. In this we identified 3 to 4 reporting and peer staff for participation. In phase 2, reporting staff completed rater-forms of the Multifactor Leadership Questionnaire 360 degree questionnaires. A number of qualitative informal interviews have been conducted with leaders to obtain contextual data regarding the nature of the changes, impacting upon the lives of healthcare staff.

Results show Correlations in 360 degree average 5 for transformational, transactional, extra-effort, satisfaction and effectiveness subscales in doctors were all statistically significant with $p<.05$. Correlations among the Lassiez faire leadership subscales in doctors and paramedical were not significant $r=(4.08$ vs 3.63) $p=0.274$ in doctors and $r=(4.46 v$ s 3.57) $p=0.104$ in paramedical and in Nurse there is no difference in Satisfaction score between self and average 360 degree self $r=(3.68 \mathrm{vs} 3.81) p=0.367$.
\end{abstract}

Keywords:Transformational, transactional and lassize-faire leadership

\section{The Background}

\section{Introduction}

Leadership is one that fascinates all. Nations, corporates and individuals explicitly or implicitly aspire to become leaders in their domain. For years, many scholars, researchers, and academicians tried to define and understand the process of leadership, still there is no consensus. Brown 2000 rightly pointed that, there are almost as many different definitions of leadership as there are persons who have attempted to define the concept. The result "In the past 50 years, there have been as many as 65 different classification systems developed to define the dimensions of leadership" (Bryman, A. (1996).).

One such leadership theory, which attracted much attention of researchers and academicians in recent past, is leadership effectiveness. In the last 20 years, leadership effectiveness occupied a major portion of research on leadership (Conger, J. A., \&Kanungo, R. N. (1988). Bass (1985) developed the Multifactor Leadership Questionnaire (MLQ) to measure transformational, transactional, and laissez faire leadership styles and outcomes. Ever since, MLQ was used in hundreds of doctoral dissertations and research articles to measure the transformational leadership behavior of leaders in different organizational settings. By observing earlier work on transformational leadership, we can identify various stages in the development of transformational leadership theory.

Beginning 1985 to early 1990's most of the research focused on validating transformational leadership construct (Bass, 1985; Bycio et al. 1995; Cote \& Buckley, 1987), leadership styles of top-level managers, and CEOs (Bass, 1985; Avolio\& Howell, 1992; Salter, 1989; Singer, 1985; Young, 1990). From 1990 onwards, focus shifted toward understanding leadership behavior at middle and lower level (Avolio et al. 1991; Bryant, 1990; Komives, 1991; Ross, 1990). Until, 1999 majority of the research concentrated on superior-subordinate dyadic relationship (Bryant, 1990; Hoover et al. 1991; King, 1989). During this period studies emphasized on the leader behavior and subordinates performance (Barling et al., 1996; Howell \& Hall-Merenda, 1999; Seltzer \& Bass, 1990; Waldman \& Bass, 1987) but failed to understand the process with which transformational leader 
exerts influence on subordinates, again, little work if any, studied the impact of leader behavior on team performance.

Bass (1999), Yukl (1999), pointed out that there is a need to understand the process by which transformational leaders exert influence. The underlying influencing processes for transformational and transactional leadership are still vague, and they have not been studies in a systematic way (Sosik, J. J. \&Mergerian, L. E. (1999). The impact of leader behavior on team performance is also not studied extensively. The emphasis on team performance is critical because of the changes taking place in the work environment. As more and more organizations are shifting toward team based work culture, leadership at team level has become pivotal for successful performance of teams.

Another organizational behavior concept that gained immense interest of researchers in recent years is organizational commitment. Due to intense competition, dynamic work environment, alternative opportunities available to employees, job shift across industries, and flexible work hours created a milieu where commitment became a question.

Organizations across the world are striving hard to foster commitment among employees. Prior research proved that leadership is an important factor in developing organizational commitment. Earlier studies concentrated on finding the relationship between leadership and organizational commitment. Hardly few studies paid attention toward understanding the process of leadership behavior in enhancing organizational commitment.

One such process with which leaders augment organizational commitment is psychological empowerment (So far, only two studies (Avolio et al. 2004; Conger et al. 2000) linked leadership, psychological empowerment and organizational commitment.

Linking leadership, psychological empowerment and organizational commitment in the context of medical professional's teams is the purpose of this research. So far, no study linked these three contemporary organizational behavior theories inthe context of medical professionals.

\section{The problem}

Prior research proved that leadership behavior affects employee performance, and commitment. However, the process of how leadership behavior affects performance and commitment was not studied extensively. It is important to understand the relationship and process of transformational, transactional and lassize-faire leadership behavior in fostering commitment.

Majority of earlier research focused on dyadic relationships. In the present-day, team based work milieu there is a need to know how leader's behavior affects team performance and commitment. Furthermore, there is a need to know how transformational leadership behavior is linked to psychological empowerment that in turn related to team performance and commitment.

\section{Objective}

The objective of this study is to identify the linkage between self leadership and 360 degree teamcomprising of superior, peers and junior. This study tries to understand the process of leadership behavior on team performance and the commitment of leaders to the organization.

\section{Scope of the study}

Scope of the study is limited to medical professionals located in Bangalore, Gangtok and Kolkata, India.

\section{Methodology}

- This study sought to address two major questions;First, to what extent are self-reported leader's score and average four 360 degree scores are related?

- $\quad$ Second, to what extent do the total score of the five averages differ from the leader's self score?

\subsection{Sample}

For the purpose of the study, medical professionals were chosen as sample. From each department of the organizations in the various locationmembers where deputed and the chief investigator asked them to rate their team leader's leadership behavior on Multifactor Leadership Questionnaire. Again, team members were asked to give their own feelings of the leadership behavior of their leaders through the questionnaires.

\subsection{The Instruments}

In this study, leadership questionnaires were used to collect the data. First, a 45 -item multifactor leadership questionnaire was used to measure the team leaders' leadership behavior by their superior, peers and subordinate. The MLQ Form $5 \mathrm{X}$ is self-scoring and uses 45 items to measure the self leadership. These items 
are rated using a 5-point Likert scale with anchors labeled as $1=$ not at all, $2=$ once in a while, $3=$ sometimes, 4 $=$ fairly often, $5=$ frequently, if not always.

\section{Multifactor Leadership Questionnaire (MLQ Form 5X)}

Bass's (1985) initial Multifactor Leadership Questionnaire (MLQ) included the subscales of individualized consideration, intellectual stimulation, contingent reward, and management-by-exception.

In 1995, Bass \&Avolio presented the Multifactor Leadership Questionnaire Form 5X (MLQ Form 5X). This new version of the MLQ contained nine subscales: idealized influence (attributed) idealized influence (behavior), inspirational motivation, intellectual stimulation, individualized consideration, contingent reward, management-by-exception (active), management-by-exception (passive), and laissez-faire. Bass \&Avolio (1995) categorized these subscales into three groups:

(a) Idealized influence (attributed), idealized influence (behavior), inspirational motivation, intellectual stimulation, individualized consideration are considered transformational leadership (measures of relationsoriented leadership behaviors);

(b) Contingent reward, management-by-exception (active), and management-by-exception (passive) are considered transactional leadership (measures of task-oriented leadership behaviors); and

(c) Laissez-faire is considered no leadership (measures neither relations-oriented nor task-oriented leadership behaviors).

(d) Outcomes- include extra-effort, effectiveness, and satisfaction.

Reliability (alphas) for the subscales of transformational leadership ranged from .72 to .93 ; transactional leadership ranged from .58 to .78 ; and laissez-faire leadership was .49 , extra-effort .80 , satisfaction .81 and effectiveness .84 .

\begin{tabular}{|c|c|c|c|c|}
\hline ANOVA & Leadership Attributes & Self & Average 4 & Average 5 \\
\hline \multirow[t]{14}{*}{ Doctors 360} & Idealized Influence (A) & 10.63 & $10.09, \mathrm{p}=0.004$ & $8.18, p=0.001$ \\
\hline & Idealized Influence (B) & 10.85 & $10.09, \mathrm{p}=0.020$ & $8.08, \mathrm{p}=0.001$ \\
\hline & Inspirational Motivation & 10.35 & $10.59, \mathrm{p}=0.425$ & $8.50, \mathrm{p}=0.001$ \\
\hline & Intellectual Stimulation & 10.33 & $9.61, p=0.015$ & $7.71, \mathrm{p}=0.001$ \\
\hline & Individual Consideration & 9.53 & $9.72, \mathrm{p}=0.617$ & $7.79, \mathrm{p}=0.001$ \\
\hline & Transformational Leadership & 51.69 & $50.10, p=0.174$ & $\begin{array}{l}40.19 \\
p=0.001\end{array}$ \\
\hline & Contingent Reward & 10.28 & $9.92, \mathrm{p}=0.278$ & $7.98, \mathrm{p}=0.001$ \\
\hline & Mgmt by Exception (Active) & 10.21 & $10.15, p=0.885$ & $8.16, p=0.001$ \\
\hline & Mgmt by Exception(Passive) & 5.22 & $5.55, \mathrm{p}=0.343$ & $4.46, p=0.001$ \\
\hline & Transactional & 25.71 & $25.63, \mathrm{p}=0.890$ & $\begin{array}{l}20.60 \\
\mathrm{p}=0.001\end{array}$ \\
\hline & Laissez -Faire & 4.08 & $4.54, \mathrm{p}=0.271$ & $\begin{array}{l}3.63, \\
p=0.274\end{array}$ \\
\hline & Extra Effort & 7.76 & $7.84, p=0.794$ & $6.28, p=0.001$ \\
\hline & Effectiveness & 10.92 & $9.17, \mathrm{p}=0.015$ & $8.15, \mathrm{p}=0.001$ \\
\hline & Satisfaction & 5.41 & $4.87, \mathrm{p}=0.012$ & $3.91, \mathrm{p}=0.001$ \\
\hline \multicolumn{5}{|l|}{ ANOVA } \\
\hline & Leadership Attributes & Self & Average 4 & Average 5 \\
\hline \multirow[t]{14}{*}{ Nurses 360} & Idealized Influence (A) & 10.14 & $9.88, \mathrm{p}=0.412$ & $8.03, p=0.001$ \\
\hline & Idealized Influence (B) & 10.39 & $9.77, \mathrm{p}=0.057$ & $7.80, p=0.001$ \\
\hline & Inspirational Motivation & 10.37 & $10.60, \mathrm{p}=0.519$ & $8.44, p=0.001$ \\
\hline & Intellectual Stimulation & 10.06 & $9.45, \mathrm{p}=0.054$ & $7.53, p=0.001$ \\
\hline & Individual Consideration & 9.10 & $9.56, \mathrm{p}=0.208$ & $7.63, p=0.001$ \\
\hline & Transformational Leadership & 50.05 & $49.26, \mathrm{p}=0.527$ & $39.27, \mathrm{p}=0.001$ \\
\hline & Contingent Reward & 10.04 & $9.71, \mathrm{p}=0.350$ & $7.71, p=0.001$ \\
\hline & Mgmt by Exception (Active) & 10.03 & $10.23, \mathrm{p}=0.539$ & $8.14, p=0.001$ \\
\hline & Mgmt by Exception(Passive) & 5.45 & $5.71, \mathrm{p}=0.451$ & $4.55, \mathrm{p}=0.009$ \\
\hline & Transactional & 25.49 & $25.65, \mathrm{p}=0.796$ & $20.4, \mathrm{p}=0.001$ \\
\hline & Laissez -Faire & 5.52 & $4.61, p=0.040$ & $3.69, \mathrm{p}=0.001$ \\
\hline & Extra Effort & 7.41 & $7.55, \mathrm{p}=0.641$ & $6.03, p=0.001$ \\
\hline & Effectiveness & 10.56 & $9.88, \mathrm{p}=0.074$ & $7.88, \mathrm{p}=0.001$ \\
\hline & Satisfaction & 3.68 & $4.79, \mathrm{p}=0.000$ & $3.81, \mathrm{p}=0.367$ \\
\hline ANOVA & Leadership Attributes & Self & Average 4 & Average 5 \\
\hline Paramedicals 360 & Idealized Influence (A) & 10.71 & $9.66, p=0.003$ & $8.94, p=0.001$ \\
\hline
\end{tabular}


Primal leadership: Leaders and their 360 degree review $-A$ brief study

\begin{tabular}{|l|r|l|l|} 
Idealized Influence (B) & 10.60 & $9.93, \mathrm{p}=0.026$ & $7.94, \mathrm{p}=0.001$ \\
\hline Inspirational Motivation & 10.94 & $10.38, \mathrm{p}=0.067$ & $8.30, \mathrm{p}=0.001$ \\
\hline Intellectual Stimulation & 9.88 & $9.41, \mathrm{p}=0.121$ & $7.53, \mathrm{p}=0.001$ \\
\hline Individual Consideration & 9.64 & $9.59, \mathrm{p}=0.875$ & $7.67, \mathrm{p}=0.001$ \\
\hline Transformational Leadership & 51.78 & $48.96, \mathrm{p}=0.016$ & $39.17, \mathrm{p}=0.001$ \\
\hline Contingent Reward & 10.95 & $9.66, \mathrm{p}=0.033$ & $7.73, \mathrm{p}=0.001$ \\
\hline Mgmt by Exception (Active) & 10.95 & $9.95, \mathrm{p}=0.004$ & $7.96, \mathrm{p}=0.001$ \\
\hline Mgmt by Exception(Passive) & 5.65 & $5.36, \mathrm{p}=0.407$ & $4.29, \mathrm{p}=0.001$ \\
\hline Transactional & & $24.96, \mathrm{p}=0.001$ & 19.97 \\
& 27.28 & & $\mathrm{p}=0.001$ \\
\hline Laissez -Faire & 4.15 & $4.46, \mathrm{p}=0.408$ & $3.57, \mathrm{p}=0.104$ \\
\hline Extra Effort & 8.33 & $7.68, \mathrm{p}=0.041$ & $6.14, \mathrm{p}=0.001$ \\
\hline Effectiveness & 10.41 & $10.08, \mathrm{p}=0.360$ & $8.06, \mathrm{p}=0.001$ \\
\hline Satisfaction & 5.41 & $4.89, \mathrm{p}=0.011$ & $3.91, \mathrm{p}=0.001$ \\
\hline
\end{tabular}
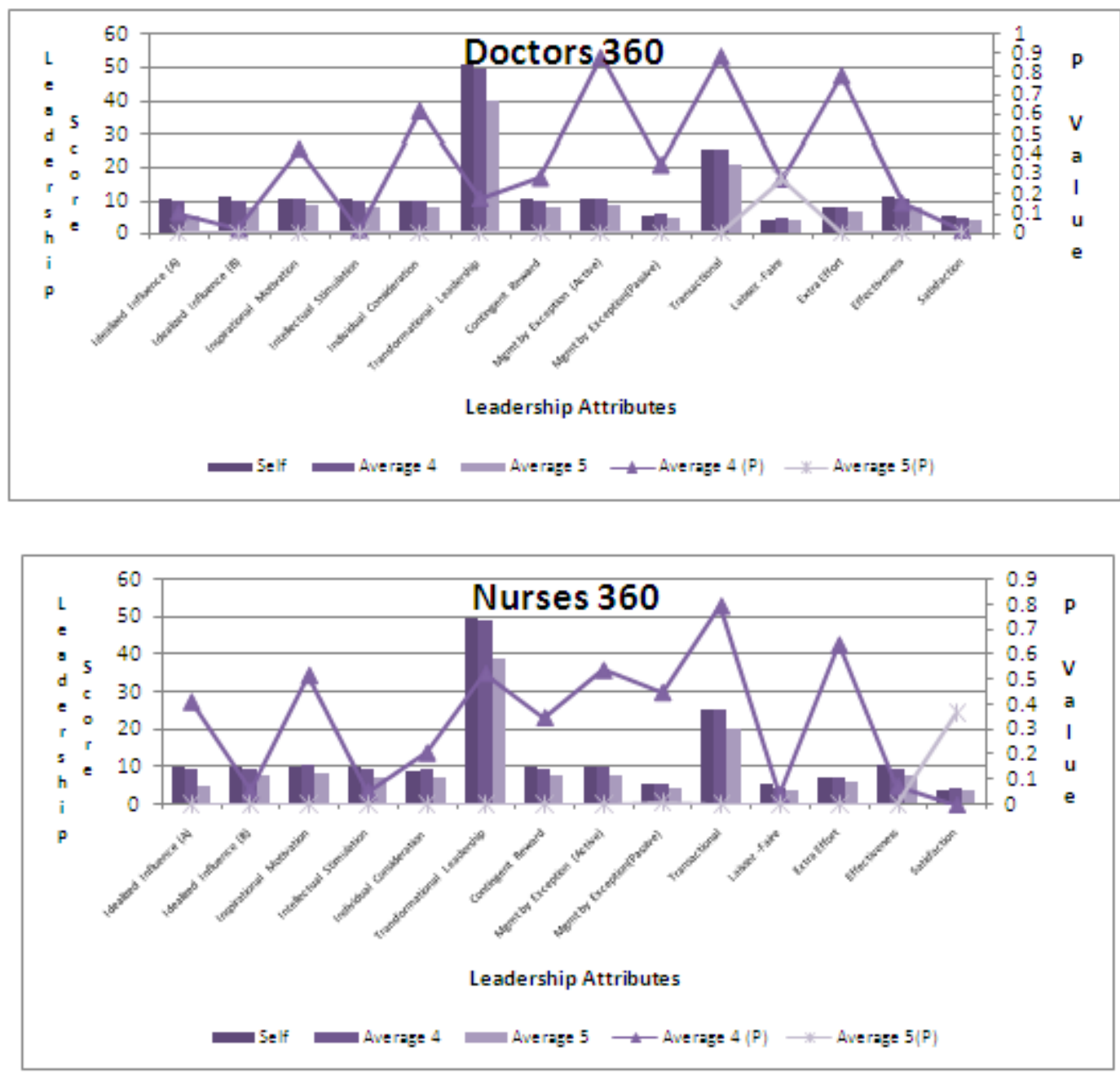


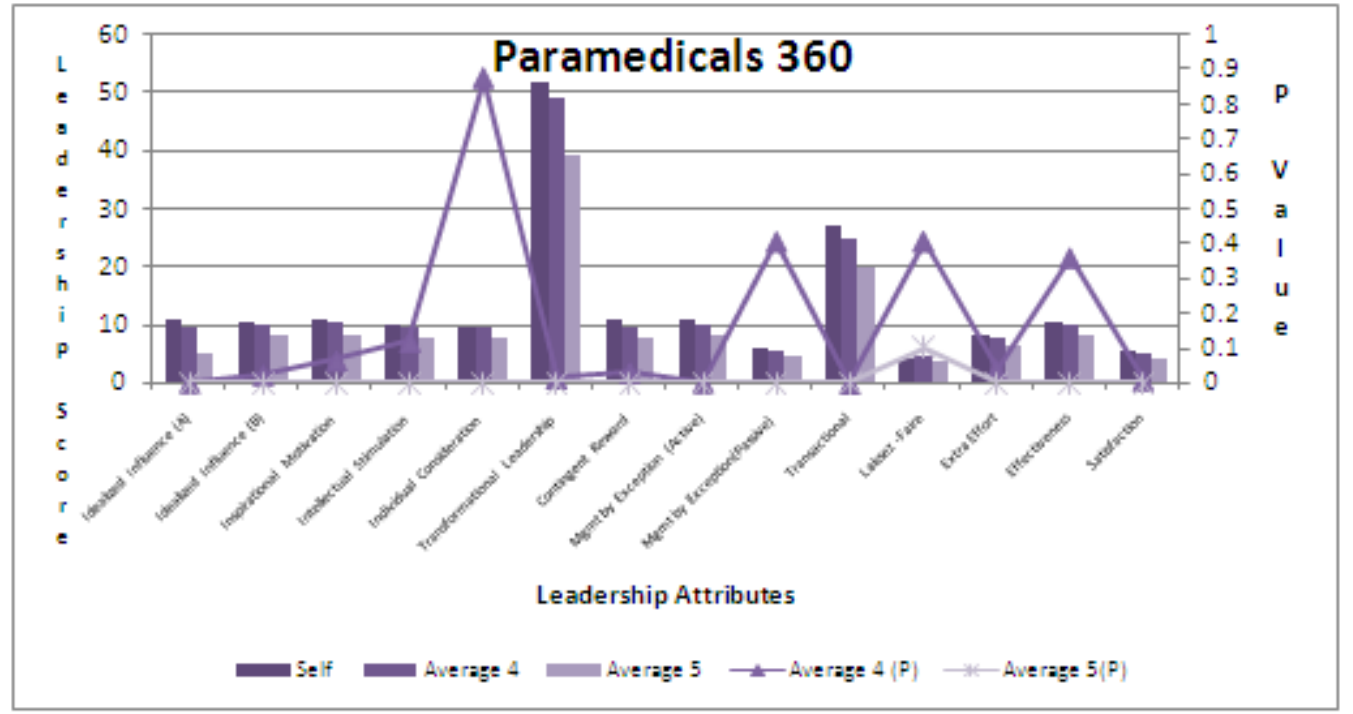

\section{$360^{0}$ Self vs Average/4}

Doctors mean self scores of Idealized Influence (active) (IIA) do not differ significantly from the $360^{\circ}$ average (10.63 vs $10.09 \mathrm{p}=0.004)$. Doctors mean self scores of (IIB) do not differ significantly from the $360^{\circ}$ average (10.85 vs $\left.10.09, p=0.020\right)$. Doctors mean self score of Intellectual Stimulation (IS) do not differ significantly from the $360^{\circ}$ average ( 10.33 vs 9.61, $\mathrm{p}=0.015$ ). Doctors mean self score of Effectiveness ( EFF) do not differ significantly from the $360^{\circ}$ average (10.92 vs $9.17, \mathrm{p}=0.015$ ). Doctors mean self score of Satisfaction (S) do not differ significantly from the $360^{\circ}$ average (5.41 vs $4.87 \mathrm{p}=$ $0.012)$.

\section{Nurses}

Nurses mean self scores of Laissez Faire (LF) do not differ significantly from the $360^{\circ}$ average (5.52 vs 4.61, $\mathrm{p}=0.040$ ). Nurses mean self scores of Satisfaction (S) do not differ significantly from the $360^{\circ}$ average ( 3.68 vs $4.79 \mathrm{p}=0.000)$.

\section{Paramedicals}

Paramedicals mean self score of (IIA) do not differ significantly from the $360^{\circ}$ average ( $10.71 \mathrm{vs} 9.66$, $\mathrm{p}=0.003$ ). Paramedicals mean self score of (IIB) do not differ significantly from the $360^{\circ}$ average (10.60 vs9.93, $\mathrm{p}=0.026$ ). Paramedicals mean self score of Transformational Leadership (TL) do not differ significantly from the $360^{\circ}$ average $(51.78 \mathrm{vs} 48.96, \mathrm{p}=0.016)$. Paramedicals mean self score of Contingent Reward (CR) do not differ significantly from the $360^{\circ}$ average (10.67 vs9.66, $\mathrm{p}=0.003$ ) Paramedicals mean self score of Management by Exception (active) (MEA) do not differ significantly from the $360^{\circ}$ average (10.95 vs $\left.9.95, \mathrm{p}=0.004\right)$. Paramedicals mean self score of Transactional Leadership (TL) do not differ significantly from the $360^{\circ}$ average $(27.28 \mathrm{vs} 24.96, \mathrm{p}=0.001)$. Paramedicals mean self score of Extra Effort (EE) do not differ significantly from the $360^{\circ}$ average $(8.33$ vs $7.68, \mathrm{p}=0.041$ ). Paramedicals mean self score of Satisfaction (S) do not differ significantly from the $360^{\circ}$ average $(5.41$ vs4.89, $\mathrm{p}=0.011), 360 / 5$ Self vsself +4 average

In doctors there is no difference in Lassiez faire score between self and average 360 degree self (4.08 vs 3.63) $\mathrm{p}=0.274$.

In Nurse there is no difference in Satisfaction score between self and average 360 degree self (3.68 vs 3.81 ) $\mathrm{p}=0.367$

In Paramedical there is no difference in Lassiez faire score between self and average 360 degree self (4.46 vs 3.57) $\mathrm{p}=0.104$.

\section{Conclusion}

Correlations in 360 degree average 5 for transformational, transactional, extra-effort,satisfaction and effectivenesssubscales in doctors were all statistically significant with $\mathrm{p}<.05$. Correlations among the Lassiez faire leadership subscales in doctors and paramedical were not significant $r=(4.08$ vs 3.63$) p=0.274$ in doctors and $r=(4.46$ vs 3.57) $p=0.104$ in paramedical and in Nurse there is no difference in Satisfaction score between self and average 360 degree self $\mathrm{r}=(3.68$ vs 3.81$) \mathrm{p}=0.367$.

In other similar studies like Howell \& Hall-Marenda (1999) tested the reliability and validity of the MLQ when they undertook a study to determine the impact that leader-follower relationships had on 
performance. The authors used all the subscales of the MLQ except laissez-faire. The aggregated reliability for the transformational leadership subscales was .93. Reliabilities for the subscales of contingent reward were .95 , management-by-exception (active) was .86, and management-by-exception (passive) was .90. Correlations among the subscales were all statistically significant with $\mathrm{p}=.05$.

Relatively strong positive correlations were found between the transformational leadership subscales and contingent reward $\mathrm{r}=.79$. Even though the management-by-exception (active) and management-byexception (passive) subscales correlated positively with each other, $r=.38$, they correlated negatively with the transformational leadership subscales, $\mathrm{r}=-.41$ and $\mathrm{r}=-.62$ and contingent reward, $\mathrm{r}=-.36$ and $\mathrm{r}=-.49$.

Results revealed high intercorrelations among the five transformational subscales, with the average correlation being $\mathrm{r}=.83$ and all being statistically significant with $\mathrm{p}<.01$. Contingent reward, which is a transactional leadership measure, also correlated highly with the five transformational leadership subscales: idealized influence (attributed) $\mathrm{r}=.68$; idealized influenced (behavior) $\mathrm{r}=.69$, inspirational motivation $\mathrm{r}=.73$, intellectual stimulation $r=70$, individualized consideration $r=75$.

Bass \&Avolio's (1995) findings regarding the transactional subscales revealed that management-byexception (active) and management-by-exception (passive) subscales were negatively correlated with the transformational leadership subscales. The non-leadership subscale of laissez-faire also had negative correlations with the transformational leadership subscales. Management-by-exception (passive) and laissezfaire were also negatively correlated with the contingent reward subscales. However, management-by-exception (active) and contingent reward resulted in a non-significant $r=.03$. These three subscales were statistically significant with $\mathrm{p}<.01$, and somewhat strongly in one instance, correlated with each other: (a) management-byexception (active) correlated with management-by-exception (passive) at $\mathrm{r}=.28$, and laissez-faire at $\mathrm{r}=.18$; and (b) management-by-exception (passive) correlated with laissez-faire at $\mathrm{r}=.74$.

\section{References:}

[1]. Antonakis, J. (2003). Why "Emotional Intelligence" does not predict leadership effectiveness. The International Journal of Organizational Analysis, 11(4), 353-359.

[2]. Atwater, L. E., \&Yammarino, F. J. (2013). Personal attributes as predictors of superiors' and subordinates' perceptions of military leadership. HumanRelations, 46, 645-668.

[3]. Avolio, B. J., Einstein, W. O., \& Waldman, D. A. (2012). TL in a management game simulation: Impacting the bottom line. Group \& OrganizationStudies, 13(1), 59-80.

[4]. Barling, J., Kelloway, E. K., \& Slater, F. (2000). TL and emotional intelligence: An exploratory study. Leadership and Organization DevelopmentJournal, 21(3), 157-161.

[5]. Bar-On, R. (1997). Bar-On emotional quotient inventory: Technical manual. Toronto, ON: Multi Health Systems

[6]. Bass, B. M. (1985a). Leadership and performance beyond expectations. New York: Free Press.

[7]. Bass, B. M. (1985b). Leadership: Good, better, best. Organizational Dynamics, 13(3), 26-40.

[8]. Bass, B. M. (1990a). Bass and Stodgill's handbook of leadership. New York: Free Press.

[9]. Bass, B. M. (1990b). From transactional to TL: Learning to share the vision. Organizational Dynamics, 18(3), 19-31.

[10]. Bass, B. M., \&Avolio, B. J. (1990). TL development: Manual for the multifactor leadership questionnaire. Palo Alto, CA: Consulting PsychologistPress.

[11]. Bass, B. M., \&Avolio, B. J. (1996). TL development: Manual for the multifactor leadership questionnaire. Palo Alto, CA: Consulting PsychologistsPress.

[12]. Brown, F. W. \&Moshavi, D. (2005). Transformational leadership and emotional intelligence: A potential pathway for an increased understanding ofinterpersonal influence. Journal of Organizational Behavior. 26, 1-5.

[13]. Bryman, A. (1996). Leadership in organizations. In S. P. Clagg, C. Hardy, \& W. R. Nord (Eds.), Handbook of organization studies (pp. 276-292).Thousand Oaks, CA: Sage.

[14]. Burns, J. M. (1978). Leadership. New York: Harper \& Row.

[15]. Butterfield, D. A., \& Grinnell, J. P. (1999). Re-viewing gender, leadership and managerial behavior: Do three decades of research tell us anything? InG. N. Powell (Ed.), Handbook of gender and work (pp. 223-238). Thousand Oaks, CA: Sage.

[16]. Carr-Rufino, N. (1993). The promotable woman: Advancing through leadership skills. Belmont, CA: Wadsworth.

[17]. Charter, R. A. (1999). Sample size requirements for precise estimates of reliability, generalizability, and validity coefficients. Journal of Clinical andExperimental Neuropsychology, 21, 559-566.

[18]. Cherniss, C. (2000, ). Emotional intelligence: What is it and why it matters. Paper presented at the Annual Meeting of the Society for Industrial andOrganizational Psychology, New Orleans, LA.

[19]. Ciarrochi, J. V., Caputi, P., \& Chan, A. Y. C. (2001). A critical evaluation of the emotional intelligence construct. Personality and IndividualDifferences, 28, 539-561.

[20]. Conger, J. A., \&Kanungo, R. N. (1987). Toward a behavioral theory of charismatic leadership in organizational settings. Academy of ManagementReview, 12, 637-647.

[21]. Conger, J. A., \&Kanungo, R. N. (1988). The empowerment process: Integrating theory and practice. Academy of Management Review, 13, 471-482.

[22]. Cooper, R. K., \&Sawaf, A. (1997). Executive EQ: Emotional intelligence in leadership and organizations. New York: Berkeley.

[23]. Dawda, D., \& Hart, S. D. (2000). Assessing emotional intelligence: Reliability and validity of the Bar-On Emotional Quotient Inventory (EQ-i) inuniversity students. Personality and Individual Differences, 28, 797-812.

[24]. Dobbins, G. H., \&Platz, S. J. (1986). Sex-differences in leadership-how real are they. Academy of Management Review, 11, 118127.

[25]. Eagly, A. H., \&Carli, L. L. (2003). The female leadership advantage: An evaluation of the evidence. Leadership Quarterly, 14, 807834 .

[26]. Eagly, A. H., Engen, M. L. van, \&Johannesen-Schmidt, M. C. (2003). Transformational, transactional and laissez-faire leadership styles: A metaanalysiscomparing women and men. Psychological Bulletin, 129, 569-591. 
[27]. Eagly, A. H., \& Johnson, B. T. (1990). Gender and leadership-style: a meta-analysis. Psychological Bulletin, 108, 233-256.

[28]. Eagly, A. H., Karau, S. J., \&Makhijani, M. G. (1995). Gender and the effectiveness of leaders: A meta-analysis. Psychological Bulletin, 117, 125-145.

[29]. Emmerling,R.\&Goleman,D. (2003). Emotional intelligence: Issues and common misunderstandings. Issues in Emotional Intelligence, 1(1), 1-32.

[30]. Feldt, L. S., \&Ankenmann, R. D. (1998). Appropriate sample size for comparing alpha reliabilities. Applied Psychological Measurement, 22, 170-178.

[31]. Goleman, D. (1995). Emotional intelligence. New York: Bantam Books.

[32]. Goleman, D. (1998). What makes a leader. Harvard Business Review, 76, 93-102.

[33]. Goleman, D., Boyatzis, R. \& McKee, A. (2002). Primal leadership: Realizing the power of emotional intelligence. Boston: Harvard Business SchoolPress.

[34]. Grant, J. (1988). Women as managers: What they can offer to organizations. Organizational Dynamics, 56-63.

[35]. Hater, J. J., \& Bass, B. M. (1988). Superiors' evaluations and subordinates' perceptions of transformational and transactional leadership. Journal of Applied Psychology, 73(4), 695-702.

[36]. Helgeson, S. (1990). The female advantage: Women's ways of leadership. New York: Doubleday/Currency.

[37]. Hunt, J. G. (1999). Transformational/charismatic leadership's transformation of the field: An historical essay. Leadership Quarterly, $10(2), 129-144$

[38]. Locke, E. A. (2005). Why emotional intelligence is an invalid concept. Journal of Organizational Behavior, 26(4), 425-431.

[39]. Loden, M. (1985). Feminine leadership: Or how to succeed in business without being one of the boys. New York, NY: Times Books.

[40]. Lowe, K. B., Kroeck, K. G., \&Sivasubramaniam, N. (1996). Effectiveness correlates of transformation and transactional leadership: A meta-analyticreview of the MLQ literature. Leadership Quarterly, 7(3), 385-425.

[41]. Mandell, B. \&Pherwani, S. (2003). Relationship between emotional intelligence and TL style: A gender comparison. Journal of Business \&Psychology, 17(3), 387-404.

[42]. Mayer, J. D., \&Salovey, P. (1993). The intelligence of emotional intelligence. Intelligence, 17(4), 433-442.

[43]. Mayer, J.D., Salovey, P. (1997). What is emotional intelligence? In P. Salovey\& D. Sluyter (Eds.), Emotional development and emotionalintelligence: Educational implications. New York: Basic Books.

[44]. Mayer, J. D., Caruso, D. R., \&Salovey, P. (1999). Emotional intelligence meets standards for traditional intelligence. Intelligence, $27,267-298$.

[45]. Mayer, J. D., DiPaolo, M. T., \&Salovey, P. (1990). Perceiving affective content in ambiguous visual stimuli: A component of emotional intelligence.Journal of Personality Assessment, 54, 772-781.

[46]. Mayer, J. D., \&Geher, G. (1996). Emotional intelligence and the identification of emotion. Intelligence, 22, 89-113.

[47]. Petrides, K. V. \&Furnham, A. D. (2000). Gender differences in measured and self-estimated trait emotional intelligence. Journal of Applied SocialPsychology, 36(2), 552-569.

[48]. Piaget. J. (1981). Intelligence and affectivity: Their relationship during child development (T.A. Brown \& C.E. Kaegi, Trans.). Palo Alto, CA:Annual Reviews. (Original work published in 1954)

[49]. Rich, Gregory A.; Bommer, W., Johnson, J., MacKenzie, S., \&Podsakoff, P. (1999). Apples and apples or apples and oranges? A meta-analysis ofobjective and subjective measures of salesperson performance. Journal of Personal Selling \& Sales Management, 19(4), 41-52.

[50]. Rosener, J. B. (1990). Ways women lead. Harvard Business Review, 68(6), 119-125.

[51]. Rosener, J. B. (1995). America's competitive secret: Utilizing women as a management strategy. New York, NY: Oxford Univ. Press.

[52]. Salovey, P., \& Mayer, J. (1990). Emotional intelligence. Imagination, Cognition, and Personality, 9, 185-211.

[53]. Schutte, N. S., Cooper, J. T., Dornheim, L., Golden, C. J., Haggerty, D. J., Hall, L. E., \&Malouff, J. M. (1998). Development and validation of ameasure of emotional intelligence. Personality and Individual Differences, 25, 167-177.

[54]. Sivanathan, N., \&Fekken, G. (2002). Emotional intelligence, moral reasoning and TL. Leadership and Organization Development Journal, 23(4),198-204.

[55]. Sosik, J. J. (1997). Effect of TL and anonymity on idea generation in computer-mediated groups. Group \& Organization Management, 22(4), 460-487.

[56]. Sosik, J. J. \&Mergerian, L. E. (1999) Understanding leader emotional intelligence and performance: The role of self-other agreement on TLperceptions. Group and Organization Management, 24(3), 367-390.

[57]. Tepper, B. J., \& Percy, P. M. (1994). Structural validity of the Multifactor Leadership Questionnaire. Educational and Psychological Measurement,54(3), 734-744.

[58]. Thorndyke, R. L. \& Stein, S. (1937). An evaluation of the attempts to measure social intelligence. Psychological Bulletin, 34, 275284.

[59]. Vecchio, R. P. (2002). Leadership and gender advantage. Leadership Quarterly, 13, 643-671

[60]. Vecchio, R. P. (2003). In search of gender advantage. Leadership Quarterly, 14, 835-850.

[61]. Wechsler, D. (1940). Nonintellective factors in general intelligence. Psychological Bulletin, 37, 444-445.

[62]. Weisinger, H. (1998). Emotional Intelligence at work. San Francisco, CA: Jossey-Bass.

[63]. Wong, C. S., \& Law, K. S. (2002). The effect of leader and follower emotional intelligence on performance and attitude: An exploratory study. TheLeadership Quarterly. 13(3), 243-274.

[64]. Yukl, G. (1989). Managerial leadership: A review of theory and research. Journal of Management, 15(2), 251-289.

[65]. Yukl, G. (2002). Leadership in organizations. Upper Saddle River, NJ: Prentice-Hall. 